Article

\title{
Purchase and Use of New Technologies among Young People: Guidelines for Sustainable Consumption Education
}

\author{
Genina Calafell ${ }^{1,2}\left(\mathbb{D}\right.$, Neus Banqué ${ }^{1,2}$ and Salvador Viciana ${ }^{2,3, *}$ \\ 1 Complex Research Group, Department of Mathematics and Science Education, Universitat Autònoma de \\ Barcelona, G5-126 Campus UAB-Bellaterra, 08193 Cerdanyola del Vallès, Spain; \\ genina.calafell@uab.cat (G.C.); Neus@rizomaedu.com (N.B.) \\ 2 Rizoma Educació Transferència de Coneixement, spin-off of the Autonomous University of Barcelona, \\ Carrer de l'Àngel, 10, 08012 Barcelona, Spain \\ 3 Catalonia School of Consumer Affairs, Catalan Consumer Agency, Generalitat de Catalunya, Carrer de \\ Pamplona, 113, 08018 Barcelona, Spain \\ * Correspondence: Genina.calafell@uab.cat or Aula.consum@gencat.cat; Tel.: +34-93-581-3203; \\ Fax: +34-93-581-1169
}

Received: 30 January 2019; Accepted: 7 March 2019; Published: 14 March 2019

\begin{abstract}
Traditional consumer education (CE), aimed at providing information and guidance to young people, has become insufficient to take on the challenges posed by the Sustainable Development Goals (SDGs), specifically SDG 12. Knowledge of youth's habits as consumers today and citizens of the future becomes essential for defining the most suitable methodological contents and strategies for effective and sustainable CE. This premise was the inception for our research project on the consumption of young people, focusing on the acquisition, purchase, and use of new technologies. Data were obtained from a sample of 994 young people who participated in activities at the Consumption School of Catalonia and completed a questionnaire. The main results revealed that young people did not include sustainability criteria in their use or purchase of technological devices, especially mobile phones: the replacement rate for mobiles was very high (1,2, or 3 years) and the most important purchase criteria were price, technical features, and brand. These results highlight the need to propose a new kind of $\mathrm{CE}$ that challenges the young to think about and adopt consumption methods adopting a contextual, constructive, and complex perspective.
\end{abstract}

Keywords: consumption education; sustainability education; new technologies; complexity; youth consumption behaviour; knowledge-generating questions

\section{Introduction}

Consumption is present in almost all of our actions today, such as washing our face, making a phone call, or turning on a light. Faced with such a ubiquitous phenomenon, both political and legislative measures are necessary and important to protect consumers' rights and duties, such as consumer education (CE), which aims to increase citizens' awareness of their own condition as consumers.

Consumer education has traditionally been based on the transfer of information to educate responsible consumers [1,2]. This education has been particularly centred on informing consumers of their rights and duties, the content of product labels, and the mechanisms and strategies employed in advertising, among other recurrent topics. Informative CE that provides closed instructions about everything that consumers need to do is not enough to handle the global and planetary challenges that citizens will face in the future. In order to urgently respond to the new scenario described by the 
United Nations Educational, Scientific and Cultural Organization (UNESCO) for 2030 [3], CE must be reconsidered, introducing teaching methods that put the focus on young consumers, who will shape society in the future. This viewpoint makes it crucial to identify youth's criteria and habits of consumption in order to understand the individual and peer lifestyle options that influence them. Knowledge of these habits will empower young people to assume responsibility for the environmental and social impact of their consumer behaviour and to question new social and cultural consumption and production methods in future settings [3].

Knowledge of the ways in which young people consume will allow us to define objectives, contents, and methodologies more pertinent to their daily lives and reality, and thus develop sustainable CE that is effective. In parallel, topics involving contents and methodologies will let teachers incorporate the Sustainable Development Goal (SDG) 12 into school activities, curriculums, and education studies.

This research focused on identifying the consumption habits of the young regarding a daily issue that is highly significant to them: the purchase, use, and handling of new technologies (New Information and Communication Technology, NICTs). This study aimed to deeply examine youth's virtual reality and their ways of consuming NICTs in order to propose guidance for CE and sustainability to work towards new ways of thinking, doing, and evaluating. This contribution could then enrich the document on educational learning objectives of the SDGs, in particular with regard to education on responsible consumption and production [4].

Literature advocating and criticising new technologies and youth is extensive and wide-ranging [5]. The present study does not seek to take a stance either for or against NICTs, but instead aimed to discover how young people consume NICTs based on three core questions:

- What presence do technological devices have in young people's lives?

- What role do young people have in buying technological devices?

- What use do young people make of the virtual world and what types of virtual spaces do they visit?

\section{New technologies, a change in the consumption model}

The presence of new technologies and the access to virtual reality in our daily lives has skyrocketed at a dizzying pace in recent years. At present, NICTs provide us with products and services useful in the home, workplace, and social and leisure spaces [6]; consequently, they change what is consumed and also how it is consumed.

The presence of NICTs in consumption has not increased homogeneously among the entire population, but has had a much more intense impact among the young [7]. Therefore, young people are considered digital natives, easily developing and quickly acquiring skills to live in the technological and virtual world $[7,8]$. Via virtual reality, young people have created action strategies and shared communication and relational codes to which adults do not always have access [9]. This fact shapes a scenario in which the young are technology experts to a much greater degree than adults, creating what is known as the digital divide [10], between digital natives and digital immigrants.

In NICT and virtual reality, the young find means to connect, communicate, learn, and satisfy their curiosity and leisure and entertainment needs, which are extraordinarily important in their daily lives [11]. The everyday presence of virtual reality in youth's social functions has changed their lifestyles [8] and the way they construct cultural meanings. Via NICT and virtual reality, the young apparently become social, cultural, and knowledge producers, as they share and put their private lives into the public sphere, as well as their experiential know-how and knowledge acquisition [12].

This situation generates the need for educational institutions, teachers, and educators to rethink how to provide consumer education for young people, who are the main group targeted for the consumption of new technologies and virtual reality.

Youth's consumption of new technologies has entailed their managing a large amount of information and, in parallel, accessing new possibilities to communicate and connect between 
individuals and groups [8], from a more horizontal and global perspective [13] in which all users can be both senders and recipients. Communication and social relationships have become an essential act, and the individualism typical of modernity seems to be changing into a new movement in search of community [14].

Enormous information storage and dissemination capacities have facilitated the emergence of an information society, namely, a society that is structured around data production, processing, and transmission [13]. In the information society, there is a huge amount and diversity of data, which are spread surpassing all temporal and spatial limits, as well as greater interactivity [15]. Virtual reality is shaped as a stage for creativity shored up by real foundations [16], but that are developed through specific rules. It is an open world with a great creative capacity, put into the hands of increasingly more people.

Another primordial feature of NICT for accessing virtual reality is its immediacy and transience. Unlike other technologies or means of communication, the NICT to access to virtual reality provide accounts that change instantly. Connectivity and coproduction is fast and seductive for young people.

The consumption of new technologies, with their social interactions and multidimensional networks, produces a new consumption logic that debunks modern consumption, called hyperconsumption [17]. Hyperconsumption establishes a new social and historical layout that is the outcome of the consumer society and mass consumption. Hyperconsumers use the internet to compare, research, analyse, reflect, and orient their desires toward that which most satisfies them. This consumer is erratic, nomadic, volatile, unpredictable, fragmented, and deregulated, as s/he is a subject freed from class standards and habits, from the weight of conventions, culture, and rules. S/he is also wary and unfaithful, since $\mathrm{s} /$ he is also freed from loyalty to a brand.

Modern-day consumers connected to the web actively guide and manage their personal journeys through the options that the consumer scenario poses to them and, via their decisions, they act as extremely valuable content producers to establish demand trends. These consumers are interactive, both consuming and producing information. Via the web, they find out about offers, share their consumer preferences and latest purchases, and much more. From here, the figure of the 'prosumer' emerges [18], a melding of consumer and producer, from the viewpoint of information and contents. The prosumer persona is a paradigmatic role in a new techno-social setting based on interactivity, in which information is both engine and product.

Young people become prosumers and hyperconsumers in the virtual world and as consumers of new technologies, creating a lifestyle (social, cultural, and financial) that reveals a transition from the big events typical of modernity toward new paradigms [19]. These new models are structured around changes in the conception of time and space and the meaning of collective action and authority [20], among others. This new model of understanding, relating to, and connecting with the world cannot exclude a perspective of social ethics, ecological values, and shared responsibility. Thus, this challenge cannot do without $\mathrm{CE}$ with a vision that incorporates new sustainable development goals.

\section{Context of research: Consumption School of Catalonia}

The Consumption School of Catalonia (ECC for its Catalan acronym) reports to the Catalan Consumer Agency, an independent institution of the Catalan government whose main purpose is to guarantee the rights of citizens as consumers. The ECC was created in 2003 and is a public and free service that aims to favour and maximise the presence of $\mathrm{CE}$ within the Catalan educational setting.

The objectives of the ECC are to:

- Establish a permanent working space for consumer education in Catalonia

- Assist the Catalan student population to access CE

- Facilitate the inclusion of CE in curriculums at different stages of the education system

To meet these objectives, the ECC proposes hosting educational workshops, promoting methodological innovation, and conducting research on the consumption habits of Catalan youth. 
- Educational workshops: On a daily basis, a team of educators offers activities that let students reflect on and gain greater knowledge of different topics related to daily consumption actions. The ECC's educational offer involves a series of activities for students from 6 to 18 years old, seminars to train teachers, activities for students with special educational needs, and workshops for families.

- Methodological innovation: The education team studies new ways to introduce CE into the school curriculum. At present, it is working on the role of questions as an engine for learning, adding art to activities, and creating hybrid and interdisciplinary spaces.

- Research on consumer habits: Descriptive research studies aim to deepen knowledge of the consumption habits of the youth in Catalonia, propose or improve upon educational workshops, and advance toward new focuses for teachers to work with CE.

The confluence of these three fields (teaching, research, and education) means that CE is shaped as a space in which research enriches daily education actions through constant innovation. This approach will constantly evolve, with the aim to stimulate the presence of consumer education in curriculums at different education stages and areas.

\section{Materials and Methods}

\subsection{Design}

The research is underpinned by the interpretative paradigm, as its purpose is to know and interpret reality in the way subjects understand it in their study context [21], in this particular case, in relation to youth's consumption habits of new technologies (purchase, use, and handing). The research aimed to explore and explain the lived reality of participants, who were young people between 12 and 16 years undertaking activities at the Consumption School of Catalonia. The ECC as a research context gives meaning to the focus of the study, namely new technologies [22].

In this sense, the research aimed to describe and understand young people's reality and different perspectives and meanings in relation to new technologies, in order to establish networks of relationships taking into account the context and incorporating their social construction [23].

More specifically, the research was a descriptive study using a questionnaire as the main data collection method. The selection of this method was appropriate because the research needed to an instrument that helped to: (a) produce data in a structured way to facilitate decision-making; (b) involve youth as self-reporters; (c) ensure precision in the process of responding to the questions [24]. The descriptive research is cross-sectional, as it plans to describe the characteristics of the population at a specific time, starting with the selection of a sample. The purpose of our research was to identify youth's consumption habits in order to obtain corroborated data so that CE activities can be developed and informative and educational policies can be designed within the framework of the Consumption School and the Catalan Consumer Agency.

\subsection{Selection and Participants}

The sample for our study comprised 944 students who participated during one academic year (September to June) in an activity offered by the Consumption School of Catalonia. The criterion for selecting the sample was random and gender and age percentages were statistically balanced (Tables 1 and 2).

Table 1. Sample (944 students) distribution and percentage by gender.

\begin{tabular}{cc}
\hline Boys & Girls \\
\hline $49.8 \%$ & $50.2 \%$ \\
\hline
\end{tabular}


Table 2. Sample (944 students) distribution and percentage by age.

\begin{tabular}{cccccc}
\hline $\begin{array}{c}\mathbf{1 0 - 1 1} \text { Years } \\
\text { Old }\end{array}$ & $\begin{array}{c}\mathbf{1 1 - 1 2} \text { Years } \\
\text { Old }\end{array}$ & $\begin{array}{c}\mathbf{1 2 - 1 3} \text { Years } \\
\text { Old }\end{array}$ & $\begin{array}{c}\mathbf{1 3 - 1 4} \text { Years } \\
\text { Old }\end{array}$ & $\begin{array}{c}\mathbf{1 4 - 1 5} \text { Years } \\
\text { Old }\end{array}$ & $\begin{array}{c}\mathbf{1 5 - 1 6} \text { Years } \\
\text { Old }\end{array}$ \\
\hline $17.9 \%$ & $16.3 \%$ & $17.3 \%$ & $16.9 \%$ & $16.2 \%$ & $15.4 \%$ \\
\hline
\end{tabular}

\subsection{Data Collection Instrument}

Data were collected by distributing a questionnaire (Figure 1) at an ECC educational activity, in which the young people reflected on their relationship to technology consumption. The questionnaire was designed through a validation and reformulation process in the framework of a pilot test. This process ensured the functionality of the questionnaire with respect to the outlined objectives and its consequent validity. The questionnaire contained dichotomous questions with two possible answers, closed multiple choice questions, and open questions. The questionnaire was divided into three blocks:

Block 1: Issues related to the technological devices that young people have

Block 2: Purchase characteristics of technological devices

Block 3: Use of devices in the virtual environment

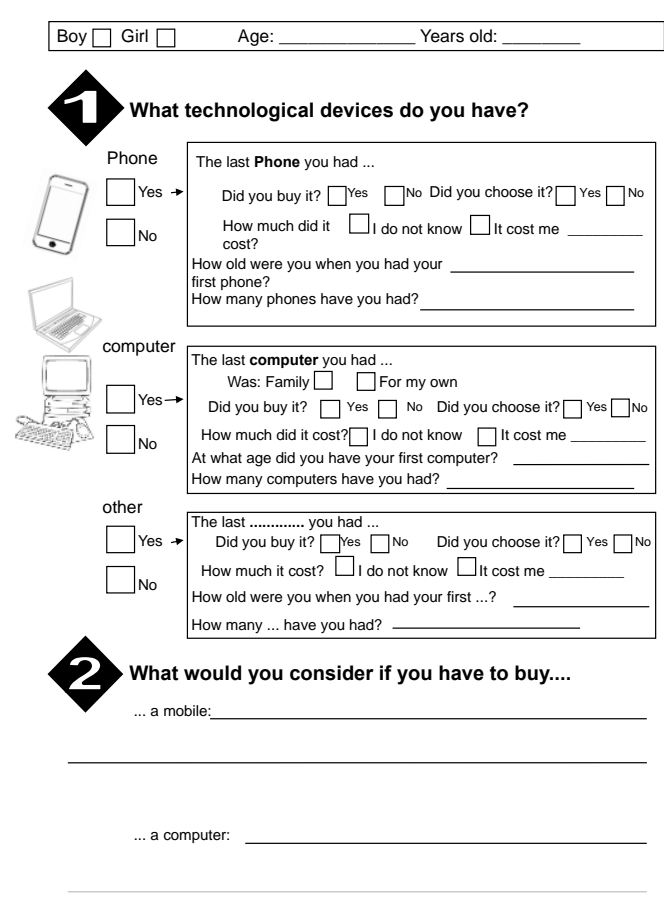

(a)

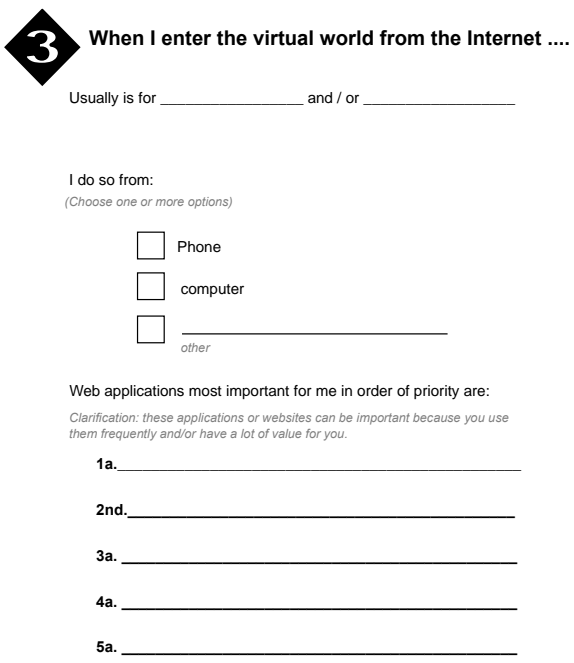

(b)

Figure 1. Worksheet with questionnaire for data collection: (a) part one of worksheet; (b) part two of worksheet.

\subsection{Data Analysis}

Data processing involved the statistical analysis of answers to the dichotomous multiple-choice questions in Block 1. The open responses from Blocks 2 and 3 were classified before handling them statistically.

Students' qualitative responses from Block 2 (i.e., features considered when buying their own mobile and/or computer) were analysed by using the analysis categories referring to youth's purchase criteria when buying a mobile/computer [25] (Table 3). Qualitative data were reduced to quantitative data, which allowed for later statistical processing. 
Table 3. Data classification tool according to the purchase criteria of youth.

\begin{tabular}{|c|c|}
\hline Category & Description \\
\hline Technical characteristics & $\begin{array}{l}\text { Each of the items that make up the technological device (screen size, memory and } \\
\text { storage capacity, operating system, processor, graphics card, resolution, etc.) }\end{array}$ \\
\hline Accessories & $\begin{array}{l}\text { Each of the items that complete the device and its functions, but are not essential } \\
\text { (Bluetooth, games, type of screen, keyboard and camera, etc.) }\end{array}$ \\
\hline Quality & $\begin{array}{c}\text { Issues that help to decide whether the device is good or bad and will be } \\
\text { long-lasting and not break }\end{array}$ \\
\hline Aesthetic & Visual appearance, without personal judgement (colour, shape, appearance) \\
\hline Weight and size & Issues related to weight and volume \\
\hline Tastes & Youth's subjective opinions \\
\hline Need & Personal judgement on how they will use it \\
\hline Practicality & Issues related to how the device operates, linked to use in youth's daily lives \\
\hline Price & Cost of product \\
\hline Promotions & Offers to induce sales \\
\hline Warranty & Issues related to ensuring that the product operates well \\
\hline Brand & Issues related to the brand \\
\hline Model & Issues related with some precision to each brand's different 'versions' \\
\hline Style & Modernity of the device \\
\hline Trend & Issues related to the supply and demand linked to social features \\
\hline Other people's opinion & Tips and recommendations from people around them \\
\hline Originality & Issues related to how this device is different from others \\
\hline Blank & No criterion \\
\hline Miscellaneous & Other \\
\hline
\end{tabular}

The qualitative data from Section 3 (i.e., most important web apps) were classified by using the tool proposed by the study of youth's internet habits and use conducted by the Ministry of Interior [26] (Table 4).

Table 4. Data classification tool according to web applications viewed by youth.

\begin{tabular}{cc}
\hline Categories of Web Apps Used \\
\hline Work/study \\
Search for information \\
Videos/series/music \\
Instant messaging \\
Social media \\
Email \\
Downloads \\
News/current events \\
Online gaming \\
Leisure and entertainment \\
Buying \\
Search engines \\
Purchases \\
Sports \\
Information \\
Games \\
TV and radio \\
Chats \\
Other
\end{tabular}


The statistical analysis of the data was conducted by the Statistics Department at the Autonomous University of Barcelona. The reading, handling, validation, and statistical analysis of the database were conducted using the software SAS V9.1 (SAS Institute Inc., Cary, NC, USA). Statistical decisions employed a significance level of 0.05 . A descriptive analysis of the sample using percentages and frequencies was conducted. From this, the most significant results that responded to the questions asked were selected and then graphically represented using bar and pie charts. The sum of all percentages was often greater than $100 \%$ because each student could choose more than one response or refer to more than one criterion in their answers. When depicting and interpreting the results, the average was also used.

\section{Results and Discussion}

The results of youth's consumption habits regarding new technologies are shown differentiating the three questions formulated.

\subsection{What Presence Do Technological Devices Have in Young People's Lives?}

To identify the presence of technological devices among young people, results were obtained with regard to the technological devices possessed (Section 3.1.1), their ages when they first obtained the technological devices they most had (Section 3.1.2), and the number (replacement rate) of these technological devices (Section 3.1.3).

\subsubsection{Which Technological Devices Do Young People Have?}

The results obtained reveal that the majority of young students had two devices that are relevant and significant in their daily lives, namely computer and mobile phone, as over $80 \%$ of the students reported having these devices (Figure 2). In addition to computer and mobile, students also had tablets and game consoles. These results are important for specifying which technological devices should be the focus when searching for results with regard to ages and replacement rates.
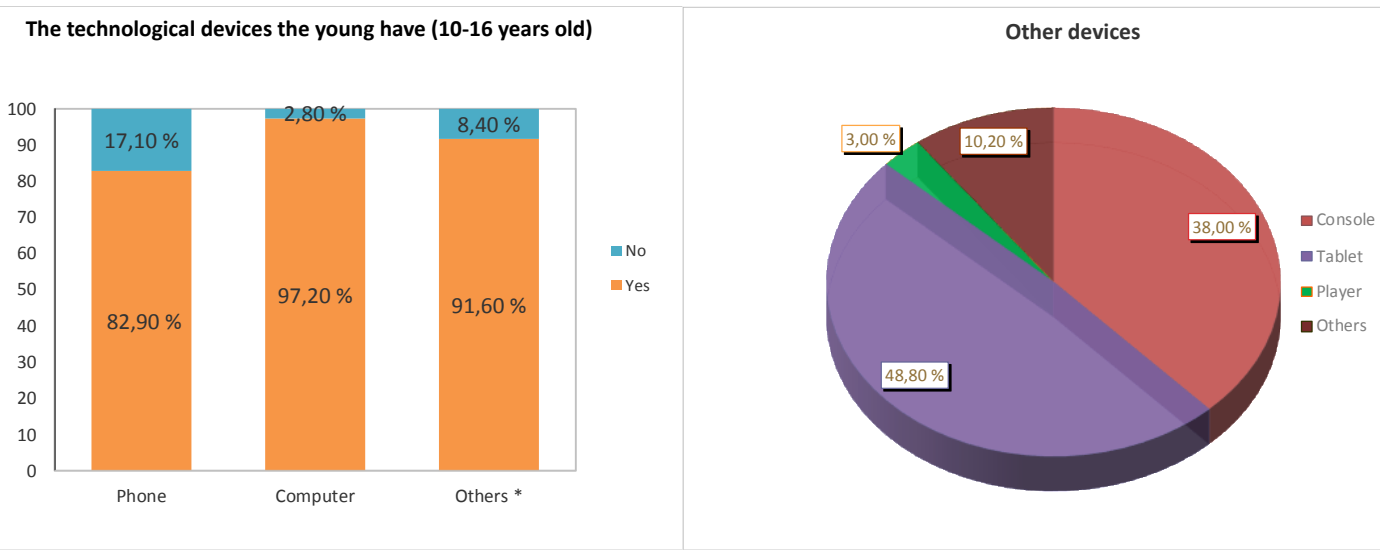

Figure 2. Charts of percentages of technological devices that young people have (10-16 years old).

\subsubsection{How Old Were Young People When They Obtained Their First Mobiles and Computers?}

Figure 3 shows that almost all students had computers and there was not much difference in ages. For mobile phones, the trend of having one grows as the young person gets older and then, from thirteen years old it doesn't change. 


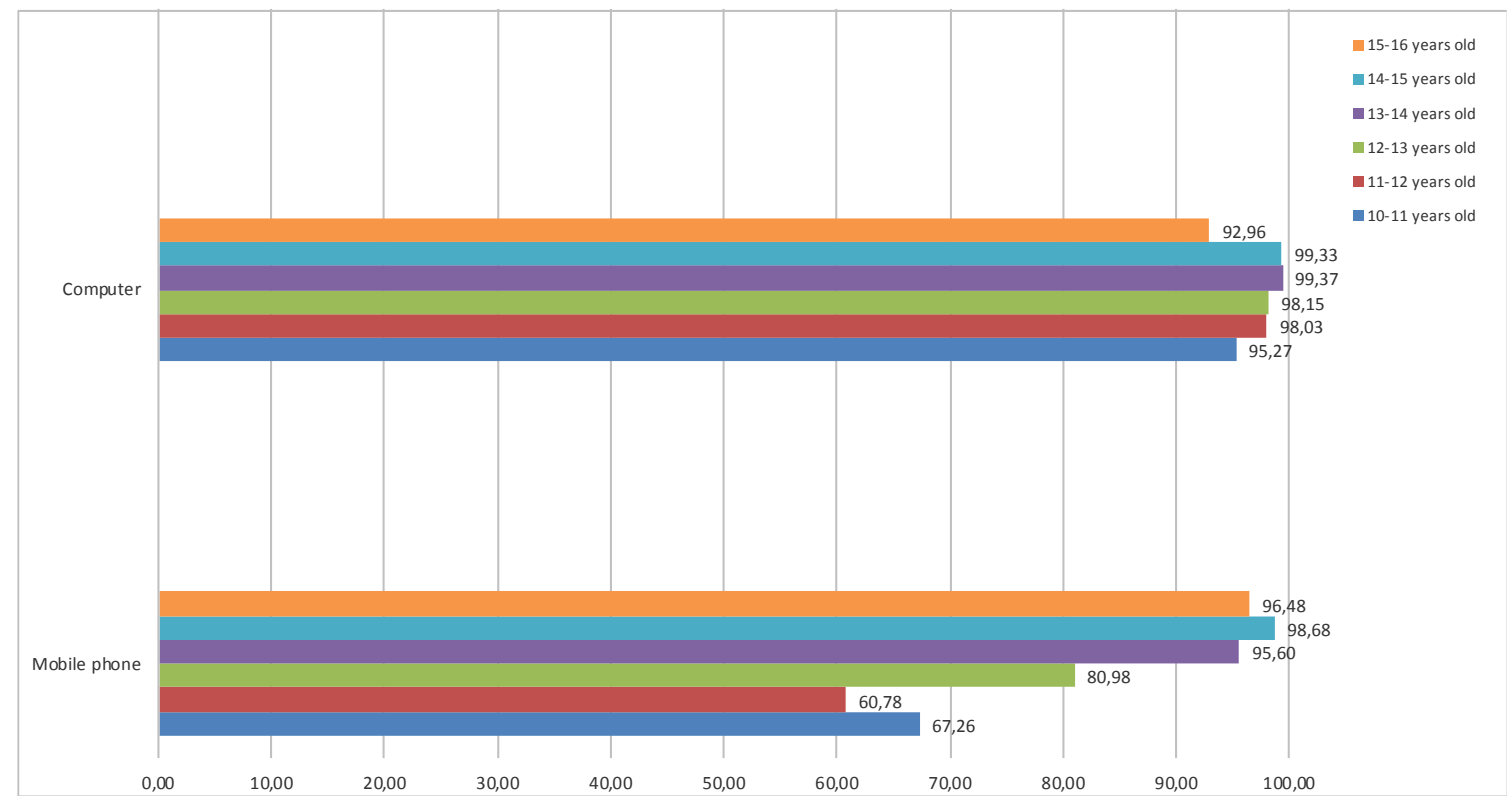

Figure 3. Chart of percentages of technological devices that young people have by age.

These results indicate that the computer is a common technological device in youth's daily lives, possibly because this device has been added and normalised within the family, which in many households becomes an electrical appliance of similar importance and scope to others such as the television. This coincides with the report de 'la sociedad en red' [27], stating that in 2016 the computer started to replace the television as the technological equipment most present in Spanish households. Perhaps the fact that the computer is a technological device conceived more as family-based and collective compared to the mobile phone, which is individual and personal, means that young people from the age of 10 have a computer for either private or family use and this situation continues as they grow older.

As for the mobile phone, behaviour is very different, as it does not have generalised immersion in young people's lives until they are 13 years of age. This result is corroborated by the results of our research, which found an average of 11 years of age. This is in agreement with other studies conducted in the autonomous community of Catalonia [28] and Spain as a whole, which establish that the young get their first mobile at 10.3 years old, and the Spanish National Statistics Institute, which states that young people have their first mobile between 11 and 12 years of age. Changing from primary to secondary school, which in Spanish education takes place between 11 and 12 years of age, seems to be one of the main factors that would explain this result. Families associate the change in schools with young people's socialisation with the mobile and, further, parents often seek the security and assurance of knowing how to locate and get in touch with their children [29].

From an educational viewpoint, anthropologists, educators, and sociologists seem to somewhat agree in recommending first mobile phones when youth are between 14 and 15 years old and mature enough to handle their phones autonomously, responsibly, and healthily.

It may seem paradoxical that young people, on the one hand, view their mobile phones as a sign and status of getting older and independent, and managing their own free time, while on the other hand, the main reason why parents buy them mobiles is to feel a sense of security and control over their children [29]. Faced with this paradox, it is important to seek educational strategies to educate both young people and families to identify the purchase of the first mobile so it is not so associated with an ideal age, but instead with a suitable context that considers a balance between the young person's personal maturity level and the school and family settings. 


\subsubsection{How Many Technological Devices Do Young People Have? (Mobile Replacement Rate)}

The average number of devices that young people have had is 2 for all cases, although regarding mobile phones, the majority have had 3 or 4 over the course of time (i.e., they change them more frequently), which was higher than the results for upgrading computers (Figure 4).

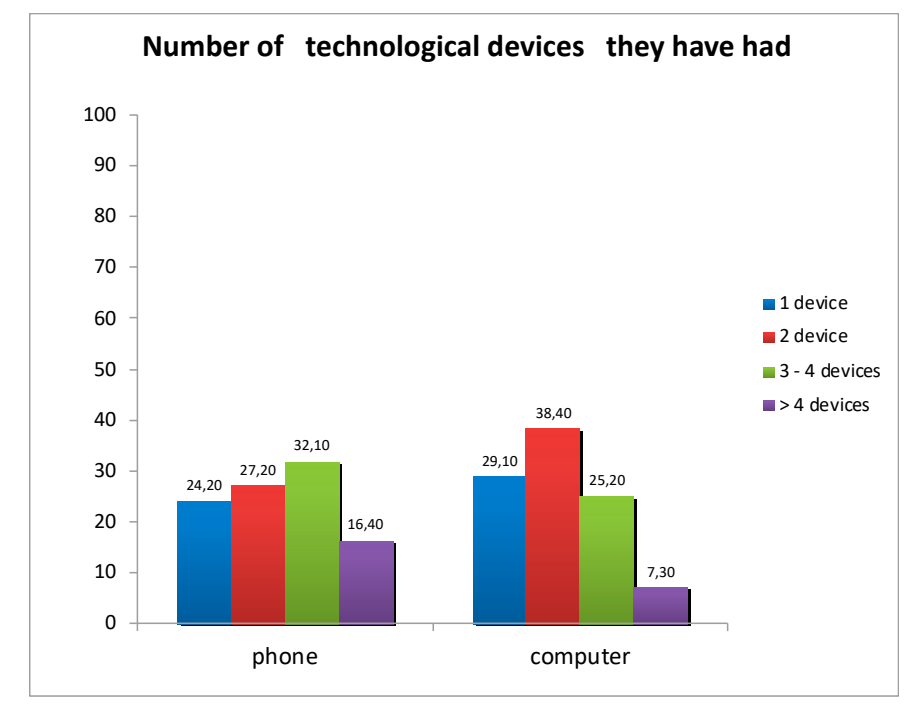

Figure 4. Chart with percentages of number of technological devices that young people have had.

When looking at the average results (Table 5), we can see that young people have had 2 mobile phones and 3 computers. The results reveal that more than half of young people change their mobiles within 2 years, and computers within 3 years or every 3 years. These rates are slightly higher than those of the adult population, as Spanish adults have their mobile phones for an average of 32 months, or almost 3 years (TNS, Global Telecom Insights (2011), viewed on the website http: / / discovermobilelife.com/ on 5 May 2011).

Table 5. Results of replacement rates of technological devices (average).

\begin{tabular}{cc}
\hline Technological Device & Average Replacement Rate \\
\hline Computer & 3 \\
Mobile & 2 \\
\hline
\end{tabular}

The ease with which young people replace their mobile devices is not an isolated incident from the buying and upgrading of other technological devices with scheduled or planned obsolescence [30]. This fact is typical of the throwaway consumer society [31], in which consumers are out of touch with product externalities (social and environmental costs) in exchange for very economical prices [32]. High mobile replacement rates among young people highlight the need for educating them about the origin and destination of technological products, what natural and human resources are needed to produce the mobile that they buy, and how the device is managed when it becomes waste. This CE should link local mobile purchases to a global and planetary consumption situation, with products' ecological footprint when buying a mobile as a citizen's choice.

\subsection{What Role Do Young People Have in Buying Technological Devices?}

To find out young people's role in buying technological devices, results were obtained with regard to purchase criteria and their participation in selecting technological devices. 
Which Purchase Criteria Are in Play for Technological Devices?

The most employed criteria-technical characteristics and price-have the most influence among youth for buying both mobiles and computers. As for the mobile phone, it merits mention that youth place more importance on criteria related to accessories, weight, and size (Figure 5).

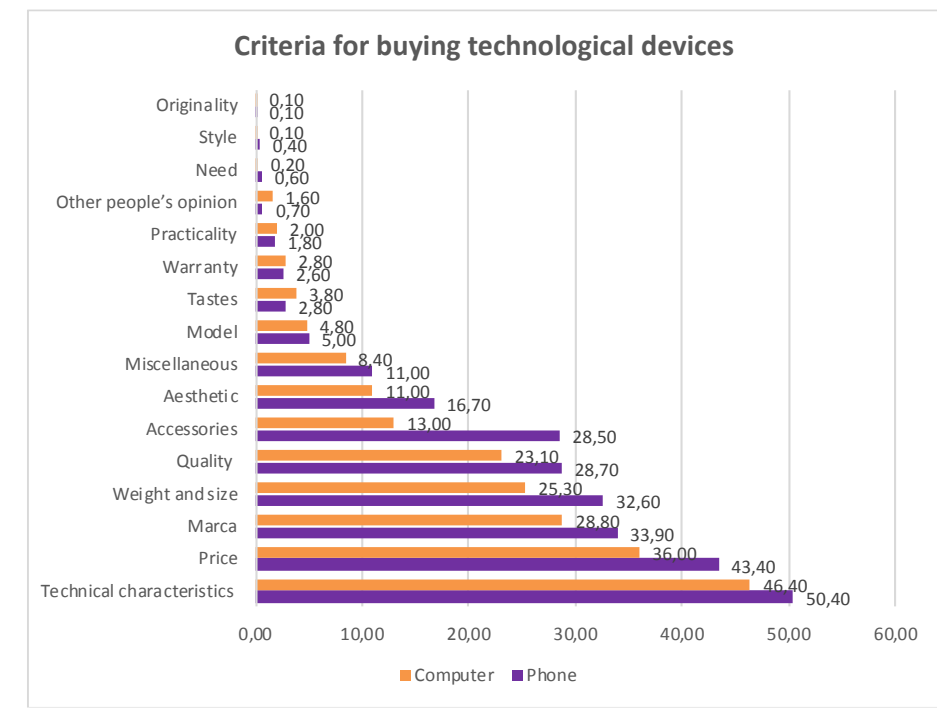

Figure 5. Chart of percentages of criteria that young people use when buying technological devices.

The results also show that young people consider and weigh up the criteria more when they want to acquire a mobile compared with a computer. This fact also corroborates the results of young people's involvement in choosing the device, its purchase, and knowledge of the price (Figure 6). As can be seen, youth report participating more in choosing and buying mobiles than computers.

This fact is explained by what was mentioned earlier about the mobile being a more personal and individual device, whereas the computer is more often shared in the household and family. This fact also reveals that young people almost never take part in buying computers.

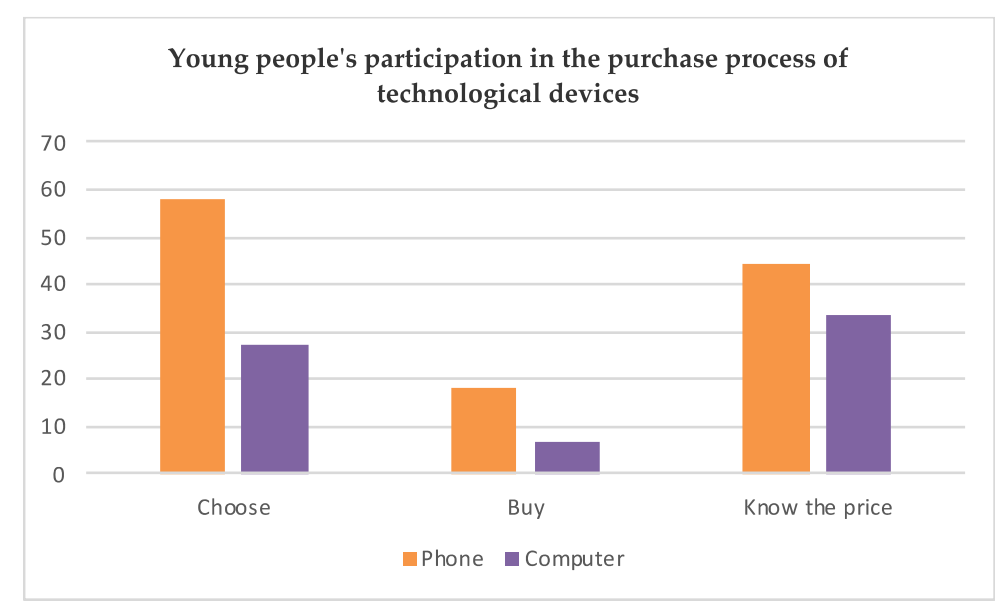

Figure 6. Chart of young people's participation in the purchase process of technological devices.

In light of these results, it seems that CE should be oriented at making young people participate more in the final purchase, as it was found that young people select the technological devices and their parents pay for them. This fact can be explained by the digital divide, as many parents may possibly prefer to delegate and trust their children with technological matters. Despite this, young people should be involved until the final purchase, so that they are aware of their rights and duties 
as consumers. Further, if young people take part in the entire purchase process, they can assess the acquisition of a technological device as a social, cultural, and ecological option in which the consuming person relates with his or her environment.

\subsection{What Do Young People Do in the Virtual World and What Types of Virtual Spaces Do They Visit?}

With regard to using new technologies (Figure 7), there is a wide range of uses, although a clear difference is detected between those that are most used and least used. The apps related to instant messaging were the most frequently used by young people, followed by those for watching videos and listening to music, for study purposes, games, and social media, which had similar percentages.

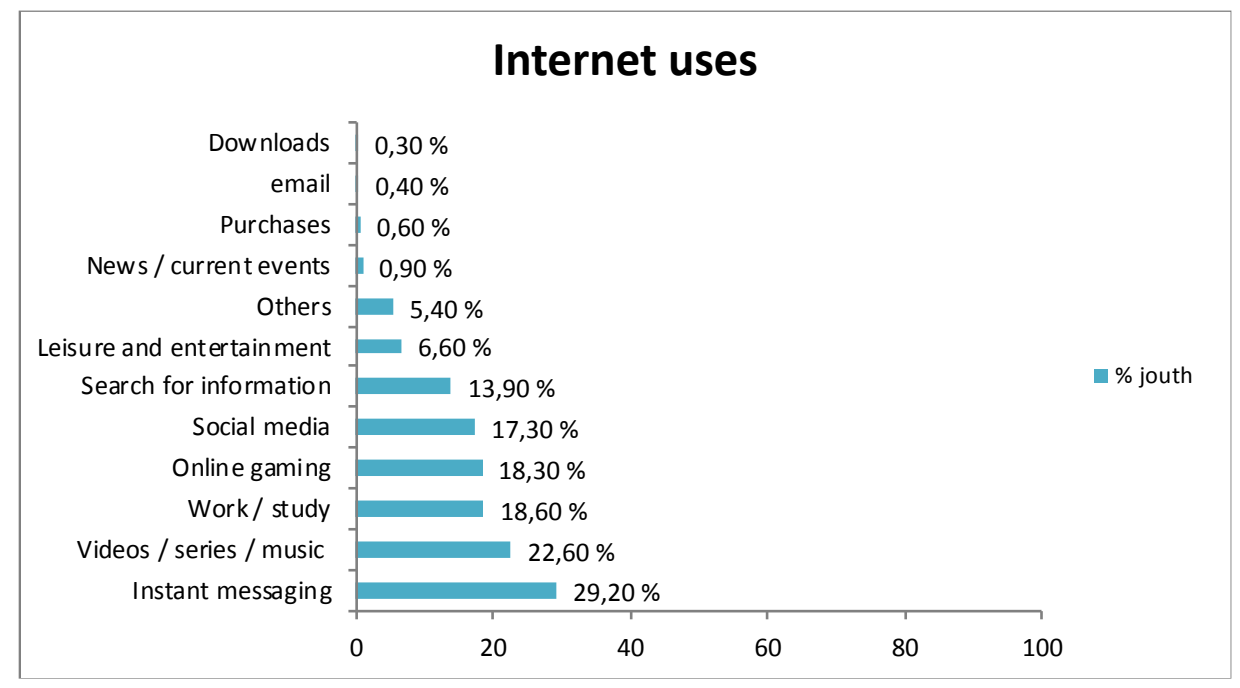

Figure 7. Young people's use of the internet.

The results reveal that young people especially use new technologies for socialising, suggesting that young people try to meet their adolescent needs in the virtual world: connecting and belonging to a group and building their identities. The use of instant messaging apps as the most frequent among young people is a characteristic of the liquid modern consumer society, where all that is instantaneous and fleeting has value [20]. The types of applications most frequently used (messaging, music and videos, for studying, and social media) highlight that it is difficult for adolescents to avoid these types of apps if they want to communicate with their friends and classmates and, in short, if they want to belong to a group. These apps in turn are changing according to the stereotypes that govern them, especially trendy or fashionable criteria, which generates peer pressure on young people to have certain applications and a perceived obsolescence of the technological devices they have due to their replacement rate (see Section 3.1.3). It is therefore important for CE and sustainability to work with the needs and desires caused by perceived obsolescence among young people, so that the trend to replace mobiles does not continue to increase. In addition to providing concepts, such CE should generate group dynamics to reflect on ethics and values in a non-dogmatic way, for example, by using methodologies from philosophy programmes for children [33]. In short, it is necessary to promote $\mathrm{CE}$ that stimulates thought among young people surrounding the idea of constructing their identities from individual and peer values that incorporate responsible and sustainable consumption.

\section{Conclusions}

Our results indicate that $\mathrm{CE}$ is necessary, and the purchase, use, and management of new technologies and the virtual world among young people becomes a good entryway for reflecting on healthier, more sustainable, and more social lifestyles. There is a need for CE that, as a priority, motivates young people to recognise each purchase action as an option that constructs their futures and that of society and the planet. 
The results related to the devices that young people most frequently have, the earliest ages at which they acquire them, and their replacement rates reveal that it is important to design CE actions that connect cognitive learning to social and emotional learning, such as the orientation for learning the SDGs [4]. From this idea, it would also be key for CE activities to work with contents such as the natural resources involved in the manufacture of technological devices, particularly mobile phones, as they are progressively becoming more essential in young people's lives, and the trend suggests increasingly higher replacement rates. This result also highlights the importance of young people's awareness of the technological waste produced due to their consumption habits; consequently, it is recommended that $\mathrm{CE}$ activities revolve around contents such as the lifecycle of mobiles and/or computers and their ecological footprints. In parallel, these contents should be linked to social and emotional issues, such as maturity to care for and maintain a technological product, and peer pressure about acquiring a mobile phone, especially in ages from 12 to 14 , when experts claim that the young are still not ready to have mobiles. For example, activities could be designed related to the diversity of materials and natural resources needed to produce a mobile phone and the origin of these resources, as well as the social, sustainability, and war conflicts stemming from resource extraction, such as nickel. Other activities could be educational actions regarding the energy required to produce a mobile, particularly the energy impact of transporting small technology pieces to different parts of the world and the $\mathrm{CO}_{2}$ footprint of this process.

Results regarding the purchase and role of technological devices point to a growing trend in young people's perceptions as active consumers in relation to selecting and as passive consumers with regard to paying. This also occurs in other consumer actions such as buying clothing and free time management [34]. This trend can be explained by the fact that increasingly more young people know exactly which products they want, participate in selecting them, and even know the price, although the final purchase is made by adults. From this perspective, $C E$ actions need to be promoted to clarify the diversity of criteria that can be used when choosing a product, going beyond the most usual criteria (brand, price, technical features) and including other aspects that involve products' sustainability and lifecycle. For example, $\mathrm{CE}$ actions should be created that work with the idea that the price of a mobile phone does not include external factors outside its production, such as sustainability and social justice criteria. Programmed obsolescence should also be considered as a core feature to reverse the tendency toward more sustainable consumption.

Finally, the results related to the use of new technologies for socialising and constructing identities reveal that $C E$ cannot neglect the personal side of consumption and individual and group values that are mobilised every time a young person enters the virtual world. Therefore, it is essential to promote contextual and meaningful EC that avoids lists of what is good and what is not good to be a good consumer. CE must start with real and controversial situations in which young people must create their own responses via thought and action. For example, situations could be proposed such as researching the journey of a mobile phone from the factory until it finally reaches the shop, or investigating the energy used according to young people's lifestyles and, thus, the apps they use.

In addition to orienting the contents of educational activities toward sustainable consumption, the results also suggest how we can work on these contents, that is, the methodological strategies of CE. One key strategy is the formulation of productive questions [35,36]. Asking young people good questions about what and how they consume helps us to avoid providing closed and repetitive information to young consumers. The formulation of questions provides an opportunity to stimulate young people to investigate and search for answers [37]. CE based on questions provides the added value of encouraging curiosity, doubts, uncertainties, reflection, and diversity. Questions also help to contextualise activities according to how meaningful they are to young people and come up with decisions that each person constructs from his or her own knowledge. In the framework of working with the SDG 12, CE that merely conveys information seeking closed responses is no longer helpful. Thus, open-ended questions must be drafted that integrate multiple dimensions and favour creativity [38]. The milestones set for the SDGs for responsible consumption and production will only 
be obtained if $\mathrm{CE}$ is promoted in which not only answers are significant but also students' capacities to formulate good questions that stimulate their questioning of phenomena in the world [36]. For example, the question 'Are applications (apps) really free?' invites the student body to consider an everyday action like installing an app and, from there, reflect on the decisions made. After identifying the different agents and factors involved in the creation, distribution, and usage process of an app, they could build models explaining the phenomenon, justifying it to their peers, and changing it, in a process of continual social interaction.

In order to achieve the SDGs for the 2030 horizon, CE would need to incorporate a constructivist and complex perspective. Such education helps consumers to be aware that every time they buy a product or hire a service, the use of natural resources is involved (water, electricity, materials, etc.) as well as by-products and waste produced that must be managed. This CE is understood as a relationship between society and the environment, and the management of the latter's resources. Consequently, educating on consumption involves educating about social and cultural lifestyles, and consumers' purchase decisions as an opportunity for transformation based on citizens' resiliency, responsibility, and sustainability.

Educating consumers who want to engage in responsible and sustainable consumption, as set out in the SDGs, must favour the training of critical, active, and responsible citizens. Critical citizens are needed, so that when faced with consumer actions, they can analyse and form their own opinions and compare different viewpoints constructively. Active citizens are required because in a democratic society, the training of people must focus on acting in relation to the environment and its transformation. This premise is linked to understanding the consumer action not as a single point, but instead as an action that takes place over time: from deciding we have a need (pre-purchase), choosing a product or service (purchase), and the use, maintenance, and disposal of what we acquired (post-purchase). Finally, responsible consumers are required because they construct their own consumer model, with which they make their own decisions, are aware of the consequences of their actions on the environment and society, and measure their impact. CE takes on a key role in progressively increasing the number of consumers who adopt a global vision of consumption and understand that consumption codes evolve quickly over time and differ depending on space and context [39].

Author Contributions: The authors have contributed equally to the work, conceptualising and designing the study, collecting and analysing data, discussing the results, and drawing conclusions.

Funding: This research was funded by Agència Catalana del Consum, Generalitat de Catalunya grant number [DOGC núm.7076, OB-02/16]. http:/ / consum.gencat.cat.

Acknowledgments: The authors wish to express their sincere gratitude to the students for their participation. This research article is part of a larger study of the collection 'Studies on consumer habits of young people in Catalonia edited by Catalonia School of Consumer Affairs of Catalan Consumer Agency.' The authors also acknowledge the support from the Research Group Complex at Universitat Autònoma de Barcelona (2017 SGR 476).

Conflicts of Interest: The authors declare no conflicts of interest. The founding sponsors had no role in the design of the study; in the collection, analyses, or interpretation of data; in the writing of the manuscript; or in the decision to publish the results.

\section{References}

1. Pujol, R.M. La educación de las personas consumidoras hoy, y su integración en el currículo escolar. Aula Innov. Educ. 2003, 127, 43-46.

2. Agúndez-Rodriguez, A. L'évolution de l'éducation à la consommation dans le contexte de la société de consommation. In Enseigner et Penser L'éducation à La Consomm; Enseigner et Éduquer à la Consummation: Quebec, QC, Canada, 2013; pp. 29-40.

3. United Nations. Sustainable Development Goals-17 Goals to Transform Our World. Available online: http: //www.un.org/sustainabledevelopment/sustainable-development-goals/ (accessed on 10 December 2018).

4. United Nations Educational, Scientific and Cultural Organization. Education for Sustainable Development Goals-Learning Objectives. Available online: https://unesdoc.unesco.org/ark:/48223/pf0000247444/ (accessed on 10 December 2018). 
5. Roca, G. Les Noves Tecnologies en Nens i Adolescents. Guia per Educar Saludablement en Una Societat Digital. Faros 2015, 1-155.

6. Comisión de las Comunidades Europeas. Libro Verde, Fomenter un Marco Europeo Para la Responsabilidad Social de Las Empresas; Comisión de las Comunidades Europeas: Brussels, Belgium, 2001.

7. Castellana, M.; Sánchez-Carbonell, X.; Graner, C.; Beranuy, M. El adolescente ante las tecnologías de la información y la comunicación: Internet, móvil y videojuegos. Pap. Psicólogo 2007, 28, 196-204.

8. Malo, S. Impacto del teléfono móvil en la vida de los adolescentes entre 12 i 16 años. Comunicar 2006, 27, 105-112, ISSN 1134-3478.

9. Bruset, S.; Sánchez, L. Adolescentes y fotoblogs: La construcción de la identidad mediante el juego. Digithum 2009, 11, 1-12.

10. Feixa, C. Generació @: La Joventut al Segle XXI; Aportacions; Biblioteca de Catalunya: Barcelona, Spain, 2001; ISBN 84-393-5435-5.

11. Machargo, S.; Luján, I.; León, E.; Martín, M. Valoración de la influencia de internet desde la perspectiva de adolescentes y jóvenes. Int. J. Dev. Educ. Psychol. 2006, 1, 223-236.

12. Brea, J.L. Cultura_RAM. Mutaciones de la Cultura en la Era de su Distribución Electronica, 1st ed.; Editorial Gedisa: Barcelona, Spain, 2007; ISBN 978-84-9784-016-3.

13. Castells, A.; Rodés, F. Com són els adolescents d'avui i com evolucionaran els seus hàbits de consum. Informe Teens; Creafutur: Barcelona, Spain, 2010.

14. Kniazeva, M.; Venkatesh, A. Food for thought: A study of food consumption in postmodern US culture. J. Consum. Behav. 2007, 6, 419-435. [CrossRef]

15. Trejo, R. Vivir en la Sociedad de la Información. Orden global y dimensiones locales en el universo digital. Rev. Iberoam. Cienc. Tecnol. Soc. Innovación 2001, 1, 1-25.

16. Lévy, P. Becoming Virtual, Reality in the Digital Age; Editorial Plenum Trade: New York, NY, USA, 1998; ISBN 10-0306457881.

17. Lipovestky, G. El Crepusculo del Deber: La Etica Indolora de los Nuevos Tiempos Democraticos; Editorial Anagrama: Barcelona, Spain, 2006; ISBN 978-84-339-1378-4.

18. Toffler, A. The Third Wave; Editorial Bantam Books: New York, NY, USA, 1980; ISBN 10-0330263374.

19. Lyotard, J.F. La condición postmoderna; Ediciones Cátedra: Madrid, Spain, 1984; pp. 1-64.

20. Bauman, Z. Una Nova Escena del Drama Entre Vell i Jove; Col-lecció aportacions: Barcelona, Spain, 2008; Volume 36, ISBN 9788439378068.

21. Denzin, N.K.; Lincoln, Y.S. Introduction: The discipline and practice of qualitative research. In The Sage Handbook of Qualitative Research; Denzin, N.K., Lincoln, Y.S., Eds.; Sage Publications: Thousand Oaks, CA, USA, 2005; pp. 1-32.

22. Latorre, A.; Del Rincón Igea, D.; Arnal, J. Bases Metodológicas de la Investigación Educative; Ediciones Experiencia: Barcelona, Spain, 1996; ISBN 84-7632-888-5.

23. De Miguel, M. Aspectos metodológicos de la investigación educativa española. In Paradigmas de la Investigación Educativa Española; Dendaluce, I., Ed.; Narcea: Madrid, Spain, 1988.

24. Meneses, J. El cuestionario. In Construcción de Instrumentos Para la Investigación en Las Ciencias Sociales y Del Comportamiento, 2nd ed.; Fàbregues, S., Meneses, J., Rodríguez-Gómez, D., Paré, M.H., Eds.; Editorial UOC: Barcelona, Spain, 2016.

25. Bonil, J.; Fonolleda, M.; Banque, N.; Calafell, G.; Querol, M. Els Joves i el nTIC D'accés a L'entorn Virtual. Estudis Sobre els Hàbits de Consum Dels Joves de Catalunya. Escola Del Consum de Catalunya; Col-lecció estudis, 6; Agència Catalana del Consum: Catalunya, Spain, 2011; ISBN 978-84-393-8682-7.

26. Ministerio de Trabajo y Asuntos Sociales. Uso de TIC, Ocio y Tiempo Libre; Ministerio de Trabajo y Asuntos Sociales: Madrid, Spain, 2007.

27. Castells, M. Internet y la Sociedad Red; Editorial Alianza: Madrid, Spain, 2006; ISBN 84-206-4784-5.

28. Viciana, S.; Banqué, N. Els Joves i el Consum Responsable: Estudis Sobre els Hàbits de Consum Dels Joves de Catalunya. Escola Del Consum de Catalunya; Col-lecció estudis, 10; Agència Catalana del Consum: Catalunya, Spain, 2015; ISBN 978-84-393-8682-7.

29. Jubany, J. ¿Hiperconectados? Educar en un Mundo Digital; Lectio Ediciones: Tarragona, Spain, 2017; pp. 1-160, ISBN 9788416918027.

30. Rodríguez, M. Obsolecencia Programada y Consumo Sostenible, Nuevos Desafíos Para la Humanidad; Observatorio Nacional para la Protección del Consumidor (ONPECO): Santo Domingo, Dominican Republic, 2018. 
31. Bauman, Z. Los Retos de la Educación en la Modernidad Líquida; Editorial Gedisa: Barcelona, Spain, 2009; pp. 1-48, ISBN 9788497842297.

32. Martínez Alier, J. Conflictos ecológicos y justiciar ambiental. Papeles 2008, 103, 1-17.

33. Agundez-Rodriguez, A. El currículo quebequense como espacio para abordar los retos de la formación de consumidores para el s.XXI. Filosofía para niños. Rev. Int. Cent. Iberoam. Filos. Niños Niñas Filos. Crianças 2014, 9, 39-60.

34. Bauman, Z. Vida de Consumo; Fondo de cultura economica de españa: Madrid, Spain, 2007; pp. 1-208, ISBN 9788437506111.

35. Bonil, J.; Junyent, M.; Pujol, R.M. Educación para la sostenibilitat desde la perspectiva de la complejidad. Rev. Eureka Enseñanza Divulg. Científica 2010, 7, 198-215.

36. Roca, M.; Márquez, C.; Sanmartí, N. Las preguntas de los alumnos: Una propuesta de análisis. Enseñanza Cienc. 2013, 31, 95-114.

37. Calafell, G.; Banqué, N.; Viciana, S. Com rutlla l'energia que consumim a l'escola? 3 claus metodològiques per reconceptualitzar l'espai aula. Perspect. Esc. 2019, 403, 58-61.

38. Pujol, R.M. Modelos de Integración de la Educación del Consumidor en el Currículum Escolar: Un Análisis Desde el Área de las Ciencias. Ph.D. Thesis, Universitat Autonoma de Barcelona (UAB), Barcelona, Spain, 1997.

39. Bonil, J.; Calafell, G.; Fonolleda, M.; Querol, M.; Pujol, R.M. À la Recherche de Pistes pour Réaliser L'éducation à la Consommation Dans un Monde en Changement; Dans Agundez, A., Jutras, F., Eds.; Enseigner et Éduquer à la Consummation: Quebec, QC, Canada, 2013; pp. 185-202.

(C) 2019 by the authors. Licensee MDPI, Basel, Switzerland. This article is an open access article distributed under the terms and conditions of the Creative Commons Attribution (CC BY) license (http:/ / creativecommons.org/licenses/by/4.0/). 